\title{
Peran Kepemimpinan Camat dalam Meningkatkan Kinerja Pegawai di Kantor Kacamatan Johan Pahlawan Kabupaten Aceh Barat
}

\author{
Wira Afrida ${ }^{1}$, Cut Asmaul Husna ${ }^{2}$ \\ ${ }^{1}$ Ilmu Adminitrasi Negara, Fakultas Ilmu Sosial dan Ilmu Politik, Universitas Teuku Umar, \\ Jl.K.H Ahmad Dahlan, Kampung Belakang, Meulaboh, 23611. \\ ${ }^{2}$ Fakultas Ilmu Sosial dan Ilmu Politik, Universitas Teuku Umar, \\ Jl.Manunggal Lr Meukuta Alam Ilie, Ulee Kareng, Banda Aceh, 23117. \\ Penulis untuk Korespondensi/E-mail: Wiraafrida2404@gmail.com
}

\begin{abstract}
Johan Pahlawan is one of the sub - district of the West Aceh Regency which is led by the head of the subdistrict of Johan Pahlawan. The purpose of this research is to determine the role of the subdistrict head leadership in improving employee performance at the Johan Pahlawan district office. The data collection techniques used observation, interviews, literature review, and preliminary journals. In this research, the researcher used qualitative methods and primary data collection, namely interviewing researchers with the respondents (the head of the subdistrict, officials, and their staff). Based on research, the head of subdistrict Leadership Role was very influential in improving employee performance at the Johan Pahlawan sub-district office, this can be seen from the leadership role and style of the head of the subdistrict which can improve employee performance in carrying out better services
\end{abstract}

Keyword: Leadership role, The head of subdistrict, Employee.

\begin{abstract}
Abstrak
Kecamatan Johan Pahlawan salah satu kecamatan di Kabupaten Aceh Barat dipimpin oleh Camat. Penelitian ini bertujuan untuk mengetahui peran kepemimpinan Camat dalam meningkatkan kinerja pegawai di Kantor Kecamatan Johan Pahlawan. Adapun teknik pengumpulan data mengunakan observasi, wawancara, kajian pustaka, dan jurnal-jurnal pendahulu. Penelitian ini penulis mengunakan metode kualitatif dan pengambilan data secara primer yaitu wawancara peneliti dengan responden (Camat, Pejabat dan staf di Kantor kecamatan Johan Pahlawan). Berdasarkan hasil penelitian, peran kepemimpinan Camat sangat berpengaruh dalam meningkatkan kinerja pegawai di Kantor Kecamatan Johan Pahlawan, Hal ini terlihat dari peran kepemimpinan dan gaya kepemimpinan Camat yang mampu meningkatkan kinerja Pegawai dalam melaksanakan pelayanan publik lebih baik.
\end{abstract}

Kata kunci: Peran Kepemimpinan, Camat, Kinerja, Pegawai.

\section{PENDAHULUAN}

Kecamatan Johan Pahlawan Kabupaten Aceh Barat terletak di Jalan Cut Meutia Gampong Ujung Baroh Kecamatan Johan Pahlawan Kabupaten Aceh Barat. Kecamatan Johan
Pahlawan Kabupaten Aceh Barat sesuai dengan Peraturan Bupati Nomor 75 Tahun 2019 Tentang Hasil Analisis Jabatan Struktural dan Jabatan Fungsional Umum Pada Sekretariat Kecamatan Johan Pahlawan memiliki tugas dan fungsi yaitu melaksanakan sebagian 
kewenangan pemerintahan di Kabupaten Aceh Barat di wilayah kerjanya yang mencakup ekonomi, bidang pemerintahan, pembangunan, pembina kehidupan masyarakat, dan kesejahteraan rakyat serta urusan pelayanan umum lainnya yang telah di serahkan oleh bupati.

Berdasarkan data kepegawaian yang terdapat pada Kantor Kecamatan Johan Pahlawan, Jumlah Pegawai Kecamatan Johan Pahlawan adalah 37 orang Pegawai dengan rincian 29 Pegawai dan 8 Tenaga Harian Lepas (THL), dari jumlah Pegawai tersebut terbagi pengurusan pada beberapa bidang yaitu ada bidang Seksi Pelayanan, Subbag Umum dan Kepegawaian, Seksi Pemerintahan, Seksi Trantib Umum, Subbag Program dan Keuangan, Seksi Kesejahteraan Sosial dan Seksi Ekonomi dan Pembangunan. Kecamatan dipimpin oleh Camat.

Peraturan Pemerintah Republik Indonesia Nomor 19 Tahun 2008 tentang Kecamatan menyebutkan Kecamatan atau sebutan lain adalah wilayah kerja Camat sebagai perangkat daerah kabupaten/kota. Pembentukan Kecamatan merupakan pemberian status pada daerah tertentu selaku Kecamatan di kabupaten/kota. Penghapusan Kecamatan merupakan pencabutan status selaku Kecamatan di daerah kabupaten atau kota. Pengabungan Kecamatan merupakan penyatuan kecamatan yang di hapus kepada Kecamatan lain (Peraturan Pemerintah Nomor 19 Tahun 2008 tentang Kecamatan).

Camat atau sebutan lain di dalam Peraturan Pemerintah Nomor 19 Tahun 2008 tentang Kecamatan disebutkan pemimpin dan koordinator penyelenggaraan pemerintahan di wilayah kerja kecamatan yang dalam pelaksanaan tugasnya memperoleh pelimpahan kewenangan pemerintahan dari Bupati/Walikota untuk menangani sebagian urusan otonomi daerah, dan menyelenggarakan tugas umum pemerintahan.

Peran kepemimpinan Camat sangat penting dalam meningkatkan kinerja pegawai. Berdasarkan pengamatan Peneliti, masih ada permasalahan di Kantor Kecamatan Johan Pahlawan yaitu rendahnya kesadaran pegawai terhadap kinerja, ini dapat dilihat dari kedisiplinan pegawai, dimana tingkat kehadiran
Pegawai masih belum optimal sesuai dengan jadwal kerja, selain itu juga para pegawai terkesan kurang motivasi berkerja serta beberapa pegawai terlihat datang terlambat dan pulang sebelum waktunya, adapun dalam melakukan absensi, pegawai juga melakukan pekerjaan tidak sesuai dengan peraturan yang sudah telah ditetapkan, sehingga dapat mempengaruhi kinerja pegawai.

Kinerja menurut Kamus Besar Bahasa Indonesia artinya sesuatu yang dicapai, prestasi yang diperlihatkan, dan kemampuan kerja (https://kbbi.web.id/kinerja). Menurut Moeheriono (2012:95) kinerja ataupun performance ialah suatu penggambaran menimpa tingkatan pencapaian penerapan sesuatu program aktivitas ataupun kebijakan dalam mewujudkan sasaran, tujuan, visi, serta misi organisasi yang dituangkan dalam sesuatu perencanaan strategis sesuatu organisasi. Menurut Veizal Rivai (2004: 304) Kinerja merupakan sikap yang nyata yang ditampilkan tiap pekerja selaku prestasi kerja yang dihasilkan oleh karyawan cocok dengan kedudukannya dalam industri.

Rendahnya kinerja Pegawai juga sangat dipengaruhi oleh peran kepemimpinan Camat. Camat memiliki tugas dan kewenangan dalam melakukan koordinasi kepada pegawai atau staf, memperhatikan kinerja pegawai, memberikan arahan, dan pelatihan kepada pegawai, sehingga pegawai memiliki kemampuan dan kinerja yang baik dalam memberikan pelayanan kepada warga.

Persoalan inilah yang mendasari peneliti tertarik melakukan penelitian bagaimana peran kepemimpinan Camat Kecamatan Johan Pahlawan dalam meningkatkan Kinerja Pegawai di Kantor Kecamatan Johan Pahlawan Kabupaten Aceh Barat.

\section{Kajian Pustaka}

Penelitian terdahulu menurut Asmara Juana Suhardi, dkk (2013) yang berjudul Kepemimpinan Camat Dalam Meningkatkan Kinerja Pegawai Pada Kantor Camat Bunguran Tengah Kabupatan Natuna. Dalam penelitian ini mengenai cara Camat Bunguran Tengah dalam memimpin masih kurang optimal sehingga peraturan dan perubahan yang dilakukan oleh Camat untuk mendorong kemampuan kinerja pegawai masih kurang dan 
pegawai tidak merasa puas (Suhardi et al, 2013).

Penelitian selanjutnya menurut Harry Murti (2013) yang berjudul Pengaruh Motivasi Terhadap Kinerja Pegawai dengan Variabel Pemediasi Kepuasaan Kerja Pada Pdam Kota Madiun. Penelitian ini menguji tentang motivasi yang berpengaruh terhadap kinerja Pegawai, motivasi juga berpengaruh pada kepuasaan kerja Pegawai, sehingga dengan begitu motivasi sangat perlu dilakukan oleh pimpinan, (Murti \& Srimulyani, 2013).

Penelitian yang dilakukan oleh Felix Semaun (1967) yang berjudul Kepemimpinan Camat Dalam Meningkatkan Disiplin Kerja Pegawai Di Kantor Camat Sungai Tebelian Kabupaten Sintang. Dalam penelitian ini membahas tentang peningkatan kedisiplinan pegawai dalam Kepemimpinan yang dilakukan oleh Camat, akan tetapi cara yang dilakukan oleh Camat belum terlaksana secara maksimal diantaranya masih banyak Pegawai yang melanggar peraturan kedisiplinan dalam jadwal kerja dan tidak konsisten dalam menyelesaikan pekerjaan sehingga perlu penindakan lebih lanjut oleh Camat, (Semaun, 1967).

Penelitian selanjutnya menurut Reni puji lestar (2013) yang berjudul Kepemimpinan Camat dalam Meningkatkan kinerja Pegawai (Studi Pada Kecamatan Mojoroto Kotipea Kediri) dalam penelitian ini membahas tentang cara Camat Mojoroto dalam pengambilan keputusan yaitu mengunakan gaya kepemimpinan situsional di mana dalam penyelesaian permasalahan yang di lakukan oleh Camat berjalan dengan baik sesuai dengan gaya kepemimpinan dalam mengambil keputusan yang di lakukan (Lestari, 2013).

Sementara dalam penelitian ini membahas tentang peran Camat dalam meningkatkan kinerja Pegawai di Kecamatan Johan Pahlawan Kabupaten Aceh Barat. Dengan tujuan untuk mengetahui Peran Kepemimpinan Camat dalam Meningkatkan Kinerja Pegawai Di Kantor Kecamatan Johan Pahlawan.

\section{Pengertian Kepemimpinan}

Pengertian kepemimpinan menurut Wahjosumidjo (1987 : 11) Kepemimpinan pada hakikatnya merupakan sesuatu yang menempel pada diri seseorang pemimpin yang berbentuk sifat tertentu seperti, Karakter (personality), Keahlian (ability) serta Kesanggupan (capability). Kepemimpinan pula selaku rangkaian aktivitas (activity) pemimpin yang tidak dapat di pisahkan dengan peran( posisi) dan style ataupun sikap pemimpin itu sendiri. Kepemimpinan merupakan proses antar ikatan atau interaksi antara pemimpin, pengikut, serta suasana.

Pengertian kepemimpinan menurut Sutarto (1998) makna kepemimpinan merupakan rangkaian kegiatan penyusunan yang berbentuk keahlian dalam seorang yang bisa pengaruhi orang lain dalam suasana tertentu buat dapat berkerja sama buat menggapai tujuan yang sudah di tetapkan.

Menurut Robbins dan Judge (2015:410) kepemimpinan merupakan keahlian pengaruhi sesuatu kelompok mengarah percapaian suatu visi ataupun serangkaian tujuan.

Kepemimpinan menurut Ordway Tead (1929) selaku temperamen merger yang membuat seorang bisa jadi bisa mendesak sebagian orang lain buat menuntaskan pekerjaan.

\section{Peran Kepemimpinan}

Kedudukan pemimpin bisa di artikan kalau selaku sikap yang di atur serta di harapkan dari seorang dalam posisi yang tertentu. Pemimpin di dalam organisasi memiliki kedudukan, jika setiap pekerjaan mempunyai harapan yang bagaimana menanggung kedudukan dalam pekerjaan. Serta pula memiliki arti kalau harapan menimpa kedudukan berarti dalam mengendalikan sikap bawahan. Kedudukan kepemimpinan bisa di artikan seperangkat perilaku yang di harapkan oleh seorang dalam perannya selaku pemimpin yang berjalan dengan sikap. Kenyataan dalam suatu organisasi mengindentifikasi pekerjaan yang wajib di coba serta sikap kedudukan yang di inginkan berjalan bersamaan pekerjaan, serta pula memiliki makna kalau harapan tentang kedudukan berarti dalam memperilakukan bawahannya. Rivai (2007:149) 
Menurut (Hadiyanti, 2015) ada 3 peran kepemimpinan yaitu:

a. Peran pemberdaya untuk mengerakkan semangat dalam diri seseorang untuk mengungkapkan bakat, kreatifitas, dan kecerdikan untuuk mampu dalam mengerjakan apapun serta konsisten dengan prinsip yang sudah di sepakati.

b. Peran pencarian alur untuk menetukan visi serta misi yang telah tentu.

c. Peran penyelaras untuk membenarkan bahwa sistem, sruktur, dan proses operasional organisasi yang memberikan dukungan setiap dalam pencapaian visi serta misi.

Kemudian, menurut Rivai $(2007 ; 150)$ perlu diperhatikan agar pemimpin tersebut dapat berperan yaitu sebagai berikut:

a. Kehidupan organisasi yang serasi serta dinamis bisa terbentuk apabila anggotanya dalam berpikir serta berperan untuk menggapai tujuan organisasi.

b. Dalam perlaku sesorang tidak berupa begitu saja, tapi melainkan melalui proses pertumbuhan serta perkembangan.

c. Saat memjadi dasar utama dalam efektivitas kepemimpinan seorang bukan dari kala menjadi bawah utama dalam daya guna kepemimpinan seseorang bukan dari penaikan ataupun penunjukan sebagai kepala, tetapi penerimaan orang lain terhadap kepemimpinan yang sudah bersangkutan.

d. Efektifitas pemimpin itu tercermin dari setiap keahlian untuk tumbuh.

e. Serta efektifitas kepemimpinan menuntut keahlian untuk membaca suasana.

\section{Azas dan Fungsi Kepemimpinan}

Dalam upaya mewujudkan kepemimpinan yang efisien hingga kepemimpinan tersebut wajib di jalankan dengan fungsinya. sehubungan dengan perihal tersebut, menurut hadari nawawi (1995: 74), fungsi kepemimpinan berhubungan langsung dengan suasana sosial dalam kehidupan kelompok yang mengisyaratkan bahwa setiap pemimpin terletak di dalam, bukan terletak di luar suasana itu pemimpin wajib berupaya supaya jadi bagian di dalam suasana sosial kelompok ataupun organisasinya.

Azas azas kepemimpinan menurut (Hadiyanti, 2015) adalah :
1. Kebahagiaan serta kesejahteraan yang lebih menyeluruh, serta mengarah pada taraf yang lebih besar.

2. Efektif teknis ataupun sosial, berkaitan dengan batasnya sumber modul serta jumlah manusia, atas prinsip penghematan terdapatnya nilai ekonomi dan azas- azas managemen modern.

3. Mengutamakan sifat manusia, ialah pembimbingan manusia buat meningkatkan kemampuan serta keahlian orang demi tujuan tentang manusia.

Dalam penelitian (Hadiyanti, 2015) dan menurut Manullang (2003) kepemimpinan memiliki fungsi yang berkaitan dengan bertanggung jawabnya sebagai pemimpin yang tertera dalam poin dibawah ini:

1. Menunjukkan perhatian kepada karyawan nya.

2. Menilai penerapan pekerjaan serta mengkomunikasikan hasilnya menghilangkan hambatan untuk melakukan pekerjann yang efektif.

3. Mendelegasikan wewenang apabila di perlukan serta mengandungkan partisipasi apabila memperbolehkannya.

4. Membagikan hadiah yang sepandan untuk bisa mendorong prestasi.

5. Mengkomunikasikan kepada karyawan tentang apa yang di harapkan oleh mereka.

6. Memenuhi para karyawan dengan sumber dana yang di perlukan untuk melaksanakan tugasnya.

7. Menentukan pelaksanaan kerja yang realistis.

\section{Gaya dan Tipe Kepemimpinan}

Dari bermacam riset tentang kepemimpinan, di ketahui terdapat sebagian gaya kepemimpinan yang paling umum, yaitu:

\section{Gaya dan tipe kepemimpinan otoriter}

Kepemimpinan otoriter, mendasarkan diri pada kekuasaan serta paksaan yang mutlak yang wajib di patuhi. Tiap kebijakan serta perintah di tetapkan tanpa bertanya dengan bawahan terlebih dulu, bahwa perlu di ketahui pemimpin bergaya dan bertipe otoriter ini senantiasa berdiri jauh dari anggota kelompoknya serta tetap mempunyai kekuatan yang tunggal yang absolut serta mempunyai suasana yang kaku, penonjolan diri yang kelebihan selaku simbol 
keberadaan organisasi, sampai cenderung serta bersikap kalau dirinya serta organisasi merupakan indentik dalam memastikan serta mempraktikkan di siplin organisasi begitu keras dengan metode menjalanknya dengan kaku, pemimpin bergaya dan tipe seperni ini pula tidak bisa dikritik serta bawahannya pula tidak bisa peluang buat membagikan anjuran maupun komentar apabila pemimpin telah mengambil keputusan, karena telah sudah mengambil keputusan, biasanya keputusan tersebut berbentuk perintah dan bawahannya tinggal melaksanakannya saja.

\section{Gaya dan Tipe Kepemimpinan Demokratis}

Gaya dan Tipe kepemimpinan demokratis ini merupakan kepemimpinan yang bereorintasi pada manusia serta membagikan tutorial yang efisien para bawahannya, ada koordinasi pekerjaan pada seluruh bawahannya dengan penekanan yang bertanggung jawab serta kerja sama yang baik, serta dia juga rela melimpahkan wewenang pengambilan keputusan kepada bawahannya.

\section{Gaya dan Tipe Kepemimpinan Kharismatik}

Gaya dan Tipe kepemimpinan kharismatik ini mempunyai kekuatan tenaga energi tarik serta bawaan yang luar biasa buat pengaruhi orang lain, sehingga memiliki pengikut yang banyak, terlepas dari apakah ia berperan selaku pemimpin resmi ataupun informal, serta ia pula mempunyai energi tarik yang kokoh untuk orang lain, sehingga orang lain itu bersedianya mengikutnya tanpa senantiasa dapat menarangkan apa pemicu kesediaannya itu. Para ahli belum setuju tentang faktor yang jadi magnit tersebut, latar belakang biografikal, pembelajaran, kekayaan serta penampilan. Bisa jadi turut berfungsi ataupun tidak, sebab ketidakmampuan para pakar mengindentifikasi faktor pemicu yang dominan, kesimpulannya di tekan kan kalau seseorang pemimpin kharismartik mempunyai kekuatan supranatural yang tidak di punyai orang lain.

\section{Gaya dan tipe kepemimpinan Leissez Faire}

Gaya dan Tipe di atas ini merupakan gaya dan tipe kepemimpinan yang aneh. di mana seorang itu di katakan pemimpin, namum pada praktisnya tidak memimpin, ini bisa dilihat pada kepemimpinan yang santai, bahwa mempunyai pemikiran organisasi tidak mempunyai permasalahan yang sungguh, serta senantiasa bisa penyelesainnya, seseorang pemimpin bergaya dan tipe ini bahagia melimpahkan wewenang kepada bawahannya serta lebih menyenangi suasana bahwa para bawahannya lah yang mengambil keputusan, serta keberadaannya dalam organisasi lebih bertabiat surportif.

\section{Gaya dan Tipe Paternalistik}

Gaya dan tipe ini merupakan seorang kepemimpinan yang menjiwai seperti kebapakan, namum buka juga tipe yang ideal yang di damba-dambakan, tapi senang menonjolkan dirinya dalam organisasi dan memperilaku bawahannya seperti anak yang belum berusia, serta ia juga tidak membiarkan kemandirian bawahannya sebab tidak mau membuat kesalahan. Hingga dari itu, kalau pemimpin paternalistik bertabiat melindungi, serta baik, tetapi metode prakteknya bertabiat negatif. Sebab dia tidak mendesak bawahannya mengambil efek di sebabkan terdapatnya akibat negatif pada organisasi. Serta dalam tiap pengambilan keputusan wajib pemimpin paternalistik yang jadi pusatnya. Serta dimana pelimpahan wewenang untuk mengambil keputusan pada tingkatan yang lebih rendah dalam organisasi tidak hendak terjalin.

\section{METODE PENELITIAN}

Penelitian ini menggunakan metode kualitatif yang bersifat diskriptif, peneliti fokus mengamati secara mendalam objek penelitian yang bertujuan untuk mendeskripsikan kedudukan kepemimpinan Camat dalam tingkatkan kinerja Pegawai di Kantor Kecamatan Johan Pahlawan Kabupaten Aceh Barat. Subjek dalam penelitian ini merupakan Camat serta kinerja Pegawai pada Kantor Kecamatan Johan Pahlawan Kabupaten Aceh Barat. Metode pengumpulan informasi yang di gunakan dalam penelitian ini merupakan observasi, wawancara, kajian pustaka dan 
Peran Kepemimpinan Camat Dalam Meningkatkan Kinerja Pegawai Pada Kantor Sekretariat Kacamatan Johan Pahlawan Kabupaten Aceh Barat

jurnal pendahulu. Dalam penlitian ini, Peneliti melaksanakan wawancara dengan narasumber yang di seleksi ialah Camat, Sekretaris Kecamatan( Sekcam), Kepala Seksi (Kasi) dan Kepala Sub Bagian (Kasubbag) di lingkungan Kantor Kecamatan Johan Pahlawan Kabupaten Aceh Barat.

\section{HASIL DAN PEMBAHASAN}

\section{Tugas dan Tanggung Jawab Camat Kecamatan Johan Pahlawan.}

Berikut tugas Camat Johan Pahlawan diantaranya:

Membuat rencana kerja berdasarkan peraturan yang berlaku untuk pedoman pelaksanaan tugas.

Camat Johan Pahlawan dalam membuat rencana kerja berdasarkan sruktur organisasi. Setiap bidang betanggung jawab atas tugas yang diberikan. Ketentuan ini dibuat berdasarkan peraturan yang berlaku dan camat menjalankannya dengan penuh tanggung jawab. Misalkan Camat membuat sebuah program 17 agustus dan dana sudah di salurkan dari pemerintah ke Camat, maka Camat yang berwenang untuk mengelolah anggaran tersebut dan rencana-rencana kegiatan yang di susun untuk 17 agustus dengan cara rapat bersama dengan pegawai dan staf untuk membuat kesempakatan dan ide dalam rangka memeriahkan hari kemerdekaan.

Membagi tugas kepada bawahannya sesuai dengan Seksi masing masing agar pelaksanaannya berjalan dengan lancar

Camat Johan Pahlawan membagikan tugas kepada Pegawai dan staf sesuai dengan seksi masing-masing diantara nya :

Seksi pelayanan, Camat memberikan tugas berupa memberikan pelayanan yang baik untuk masyarakat adapun tugas nya ialah memimpin seksi pelayanan dalam melaksanakan penyelengaraan pelayanan adminitrasi kependudukan, perizinan dan non perizinan sesuai ketentuan peraturan per undang-undang untuk mendukung kelancaran tugas pokok Camat Johan Pahlawan.

Seksi Trantib umum, melaksanakan aktivitas pengelolaan yang meliputi penyiapan bahan, koordinasi serta penyusun laporan di bidang informasi kentrentraman serta kedisiplinan umum cocok dengan syarat buat kelancaran tugas pokok seksi ketentraman serta kedisiplinan umum.

Seksi pemerintahan, memimpin seksi pemerintahan di Kecamatan Johan Pahlawan menyiapkan bahan penyelengaraan pemerintahan umum dan pembinaan, keagrariaan, pemilihan umum, pemilihan kepala daerah, pemilihan mukim, dan pemilihan geucik gampong, tata batas wilayah, pembinaan pemerintahan dan aparatur serta adminitrasi pemerintahan mukim dan gampong sesuai peraturan per undang-undang. serta melaksanakan aktivitas yang meliputi penerimaan, pencatatan serta pendokumentasian di bidang pertanahan cocok dengan syarat yang berlaku untuk kelancaran tugas pokok seksi pemerintahan.

Subbag bagian program serta keuangan, menerima aktivitas penerimaan, pengumpulan, pengklasikasian serta penelahaan informasi objek kerja di bidang laporan keuangan cocok syarat untuk menunjang kelancaran tugas pokok subbag bagian program serta keuangan.

Subbag bagian Umum serta Kepegawaian, melaksanakan aktivitas yang meliputi penerimaan, pencatatan serta pendokumentasian di bidang kepegawaian cocok syarat untuk kelancaran tugas pokok Subbag Bagian Umum serta Kepegawaian.

Memberikan petunjuk kepada bawahannya berdasarkan pembagian tugas agar memahami tugasnya

Camat Johan Pahlawan ini dalam membimbing pegawai dan staf nya ialah dengan melaksanakan rapat di mana dalam rapat tersebut Camat mengarahkan pegawai dan staf nya jika menerima kritikan dari masyarakat misalnya krtik dalam pelayanan, maka Camat memberikan arahan dan menyarankan untuk melakukan perubahan terhadap kinerja Pegawai dan staf di kantor Kecamatan Johan Pahlawan.

Mengawasi pelaksanaan pekerjaan bawahan dan mengevaluasi hasilnya secara langsung 
atau melalui pelaporan untuk mengetahui kelancaran serta hambatan yang terjadi

Dalam perihal ini dari wawancara yang di coba dengan Camat sendiri pula bisa di katakan kalau pengawasan telah seperti di jalani di dalam kantor serta itu telah berjalan, ini terlihat dari pernyataan Camat yang menerangkan kalau dalam seminggu mereka mengadakan rapat pegawai serta staf selaku penilaian serta kunjungan ke ruangan- ruangan selaku kontrol kerja langsung. Di Kecamatan Johan Pahlawan sendiri warga pula bisa membagikan pengawasan terhadap kerja Pegawai kantor lewat anjuran ataupun kritik yang bisa di sampaikan secara langsung pada waktu melaksanakan pelayanan, namum apabila dalam proses pengawasan ini terjalin penyimpangan ataupun suatu yang melanggar ketentuan, hingga pegawai di kenakan sanksi.

Memotivasi bawahan dengan memberikan perhatian dan perhargaan untuk meningkatkan produktifitas kerja dan pengembangan karya

Pemimpin memotivasi bawahan dengan membagikan hadiah kepada mereka yang berprestasi baik. Dengan ini menumbuhkan semangat kerja bawahan nya hendak tingkatkan sebab manusia pada biasanya bahagia menerima yang baik.

Mengkoordinasi kegiatan pemberdayaan masyarakat gampong melalui bimbingan dan pelatihan untuk peningkatan kualitas hidup masyarakat gampong

Memberikan pemberdayaan kepada aparat gampong melalui kegiatan contoh misalnya Kegiatan bimtek pengelolaan dana desa.

Mengkoordinasikan kegiatan ketentraman dan ketertiban umum sesuai dengan ketentuan agar terciptanya lingkungan damai di masyarakat Menertibkan desa-desa demi keamanan bisa dengan menggalakan kebersihan di setiap desa dan menghidupkan kembali poskamling

Mengkoordinasikan penyelengaraan kegiatan yang dilakukan oleh perangkat daerah ditingkat kacamatan melalui kegiatan-kegiatan agar tepat sasaran

Contohnya seperti melakukan kegiatan majelis taklim di tingkat Kecamatan Johan Pahlawan yang di laksanakan di mesjid agung mulaboh.
Mengatur pembinaan dan pengawasan penyelengaraan pemerintahan mukim dan gampong

Camat berperan dalam mengatur pembinaan dan pengawasan penyelenggaraan Mukim dan Gampong melalui imum mukim, Keuchik dan aparatur gampong agar masyarakat mampu membangun gampongnya masing-masing.

Mukim atau nama lain, adalah kesatuan masyarakat hukum dalam Provinsi Nanggroe Aceh Darussalam yang terdiri atas gabungan beberapa Gampong yang mempunyai batas wilayah tertentu dan harta kekayaan sendiri, berkedudukan langsung di bawah Camat atau nama lain yang dipimpin oleh Imeum Mukim atau nama lain (Qanun Provinsi Nanggroe Aceh Darussalam Nomor 4 Tahun 2003 Tentang Pemerintahan Mukim Dalam Provinsi Nanggroe Aceh Darussalam).

Pembinaan dan pengawasan Camat ddalam penyelenggaraan Pemerintahan di Gampong misalnya pemilihan Keuchik yang dilaksanakan untuk memilih pemimpin terbaik di gampong yang akan mempunyai kekuasaan dan wewenang untuk mengendalikan pembangunan gampong yaitu selama 6 tahun masa jabatan Keuchik yang mengedepankan asas langsung umum, bebas dan rahasia oleh warga gampong setempat.

Mengkoordinasikan pelaksanaan kewenangan pemerintah Kabupaten yang dilimpahkan kepada masyarakat melalui Camat dan para muspika agar jalannya program dan kegiatan kabupaten di Kecamatan

Dengan melakukan kegiatan program desa, misalnya desa membangun atau melakukan kegiatan penobatan Gampong teladan.

Serta bertanggung jawab terhadap kelancaran penerapan program serta terselengaranya aktivitas di Kecamatan Johan Pahlawan serta di samping itu terhadap pengawasan Bertanggung jawab terhadap kebenaran, ketepatan serta kecepatan penerapan tugas, permasalahan serta program yang bisa melaksanakan pembinaan segala Pegawai serta pelaksanaan di siplin kerja di Kecamatan Johan Pahlawan, serta Bertanggung jawab terhadap kerahasiaan pesan, dokumen, informasi serta data di Kecamatan Johan Pahlawan. 
Peran Kepemimpinan Camat Dalam Meningkatkan Kinerja Pegawai Pada Kantor Sekretariat Kacamatan Johan Pahlawan Kabupaten Aceh Barat

\section{Peran Kepemimpinan Camat Dalam Meningkatkan Kinerja Pegawai \\ Camat berperan dalam hal sebagai berikut di antaranya:}

Peran pemberdaya untuk mengerakkan semangat

\section{Kebersihan Kantor}

Setiap hari menjaga kebersihan ruangan kantor agar kerja Pegawai menjadi nyaman dan terhindar dari aroma tidak sedap, bakteri dan virus. Apalagi saat ini kesehatan dan kebersihan sangat perlu di jaga di masa pendemi wabah penyakit yang melanda ini.

\section{Mengadakan rapat}

Dalam hal ini camat membimbing dan mengarahkan staf nya dengan melakukan rapat koordinasi setiap minggunya. Sehingga dengan begitu kinerja pegawainya semakin terlatih dan semangat menjalaninya.

Memberikan motivasi kerja kepada pegawai. Setiap pemimpin bahkan Camat sekalipun wajib kiranya untuk memberikan suport dan motivasi kerja kepada bawahannya. Agar setiap motivasi itu bisa menjadi bahan dan dukungan untuk kinerja Pegawai menjadi lebih baik lagi.

\section{Memberikan bonus}

Setiap pekerjaan yang diberikan lebih melebihi sebelumnya, Camat yang hendaknya memberikan bonus kepada Pegawai agar semangat dalam menyelesaikan tugas yang menumpuk.

\section{Gajian}

Dalam hal gajian ini di cairkan sesuai tanggal dan tidak di tunda-tunda karena menyebabkan semangat kerja bagi Pegawai.

Peran pencarian alur untuk menetukan visi dan misi yang sudah pasti.

\section{Pembagian Tugas}

Membagikan petunjuk kepada bawahannya bersumber pada pembagian tugas supaya menguasai tugasnya.

\section{Pembelian Bon Alat Tulis Kantor}

Bendahara barang harus mencatat kir aset setiap bidang dan pembelian alat tulis kantor bon harus mempunyai tanda tangan pemegang barang dan mengetahui sekcam Kecamatan Johan Pahlawan.
Gotong Royong

Setiap hari jumat melakukan gotong royong dan membuat bubur.

\section{Kedisplinan}

Bekerja sesuai dengan jam kerja yang telah tentukan khususnya pelayanan masyarakat.

\section{Peran penyelaras}

Camat berperan sebagai sumber informasi, yaitu menyampaikan informasi penting yang berkaitan dengan keadaan pemerintahan khususnya di wilayah kecamatan Johan Pahlawan. yang di lakukan Pegawai dan staf di Kantor Kecamatan Johan Pahlawan, Apel Pagi adalah kegiatan rutin yang di lakukan setiap hari senin. Hal ini dilakukan melalui Apel Pagi yang dilaksanakan di mulai pukul $08.00 \mathrm{~s} / \mathrm{d}$ selesai.

\section{Gaya dan Tipe Camat Johan Pahlawan} dalam meningkatkan Kinerja Pegawai Gaya dan tipe kepemimpinan Camat Johan Pahlawan yaitu demokratis yang bereorientasi serta membagikan tutorial yang efisien pada bawahannya ada koordinasi pekerjaan pada seluruh bawahannya dengan penekanan yang bertanggung jawab serta kerja sama yang baik, serta rela melimpahkan wewenang pengambilan keputusan kepada bawahannya.

\section{Kinerja Pegawai Kantor Kecamatan Johan Pahlawan}

Dari pengamatan peneliti selama melakukan magang di kantor Kecamatan Johan Pahlawan Kabupaten Aceh Barat, sudah ada perubahan pada Pegawai dan staf di Kantor Camat Johan Pahlawan yaitu pada sebelumnya masih rendahnya kesadaran Pegawai terhadap kinerja, yang dapat di lihat dari kedisiplinan pegawai, di mana tingkat kehadiran pegawai masih belum optimal sesuai dengan jadwal kerja, selain itu juga para Pegawai terkesan kurangnya motivasi berkerja serta beberapa Pegawai terlihat datang terlambat dan pulang sebelum waktu nya, adapun dalam melakukan absensi Pegawai juga tidak sesuai dengan peraturan yang telah di tetapkan, sehingga mempengaruhi kinerja Pegawai. Dan setelah pergantian Camat beberapa minggu yang lalu sudah ada perubahan yang di mana staf dan pegawai yang lain terlihat datang terlambat dan pulang sebelum waktunya, sekarang sudah mulai di siplin datang dan pulang pada 
waktunya sudah ada meningkat dari sebelumnya.

\section{KESIMPULAN}

Berdasarkan hasil dan pembahasan dalam penelitian ini dapat di simpulkan bahwa Peran Kepemimpinan Camat Dalam Meningkatkan Kinerja Pegawai di Kecamatan Johan Pahlawan Kabupaten Aceh Barat berdasarkan Gaya dan tipe kepemimpinan Camat Johan Pahlawan yaitu demokratis yang bereorientasi pada manusia serta membagikan rutorial yang efisien para bawahannya bawahannya terdapat koordinasi pekerjaan pada seluruh bawahannya dengan penekanan yang bertanggung jawab dan kerja sama yang baik, serta ia juga rela melimpahkan wewenang pengambilan keputusan kepada bawahannya. Bahwa gaya dan tipe ke pemimipinan ini sesuai dengan penerapan kepemimpinan sesuai peraturan yang berlaku.

Kinerja Pegawai Kantor Kecamatan Johan Pahlawan sudah ada perubahan pada pegawai dan staf di Kantor Camat Johan Pahlawan yaitu pada sebelumnya masih rendahnya kesadaran Pegawai terhadap kinerja, yang dapat dilihat dari kedisiplinan Pegawai, di mana tingkat kehadiran pegawai masih belum optimal sesuai dengan jadwal kerja, selain itu juga para pegawai terkesan kurangnya motivasi berkerja serta beberapa pegawai terlihat datang terlambat dan pulang sebelum waktu nya, adapun dalam melakukan absensi Pegawai juga tidak sesuai dengan peraturan yang telah di tetapkan, sehingga mempengaruhi kinerja Pegawai. Dan setelah pergantian Camat beberapa minggu yang lalu sudah ada perubahan yang di mana staf dan Pegawai yang lain terlihat datang terlambat dan pulang sebelum waktunya, sekarang sudah mulai di siplin datang dan pulang pada waktunya sudah ada meningkat dari sebelumnya.

Peran Kepemimpinan Camat Dalam Meningkatkan Kinerja Pegawai, yaitu Peran pemberdaya untuk mengerakkan semangat, Peran pencarian alur untuk menetukan visi serta misi yang telah tentu, serta peran penyelaras. Kedudukan yang telah di jalankan oleh Camat itu telah efisien. Dalam penyusunan ini masih banyak kekurangannya buat itu penulis mengharapkan kritik, masukan, serta anjuran dalam penyusunan ini. Agar penyusunan ini dapat bermafaat untuk pembaca.

\section{REFERENSI}

Fadhli, M., Sos, S., \& Si, M. (2014). Camat dan Kecamatan menurut UU No 23 Tahun 2014. (23), 1-6.

Hadiyanti, H. (2015). Peran Kepemimpinan, Kinerja PENDAHULUAN Latar Belakang Kepemimpinan Pengertian Kepemimpinan. 3(1), 206-219.

Lestari, R. (2013). Kepemimpinan Camat Dalam Meningkatkan Kinerja Pegawai (Studi Pada Kecamatan Mojoroto Kota Kediri). Jurnal Administrasi Publik Mahasiswa Universitas Brawijaya, 1(3), 157-164.

Murti, H., \& Srimulyani, V. A. (2013). Pengaruh Motivasi Terhadap Kinerja Pegawai Dengan Variabel Pemediasi Kepuasaan Kerja Pada Pdam Kota Madiun. JRMA Jurnal Riset Manajemen Dan Akuntansi, 1(1), 10-17.

Semaun, F. (1967). Kepemimpinan camat dalam meningkatkan disiplin kerja pegawai di kantor camat sungai terbelian kabupaten sintang. 36 Perahu, 5(1), 3544.

Suhardi, A. J., Suni, B., Syafei, M., Studi, P., Negara, A., \& Pontianak, U. T. (2013). Kepemimpinan camat dalam meningkatkan kinerja pegawai pada kantor camat bunguran tengah kabupatan natuna. 1-17.

http://materibelajar.co.id/pengertian-kinerjamenurut-para-ahli http://sinta.unud.ac.id

Peraturan Pemerintah Republik Indonesia Nomor 19 Tahun 2008 Tentang Kecamatan

Qanun Provinsi Nanggroe Aceh Darussalam Nomor 4 Tahun 2003 Tentang Pemerintahan Mukim Dalam Provinsi Nanggroe Aceh Darussalam

Peraturan Bupati Aceh Barat Nomor 75 Tahun 2011 Tentang Hasil Analisis Jabatan Struktural dan Jabatan Fungsional Umum Pada Sekretariat Kacamatan Johan Pahlawan 